\title{
A quantitative field comparison of emergence traps with open and covered bottoms in a stream : general and Trichoptera
}

\author{
H. Malicky 1
}

Keywords : emergence traps, quantitative emergence, stream, Trichoptera.

Two greenhouses were operated as emergence traps in a stream in southwestern Lower Austria from 1984 to 1989 at a distance of $28 \mathrm{~m}$ from each other. The stream bed under the traps was covered by a metal sheet alternately for one year, thus preventing emergence under the trap with covered bottom so that insects caught in this trap must have come from outside. The results have shown that insects from outside constitute a high but un quantifiable proportion of the total catch. In many instances there were more insects in the trap with a covered stream bed than in the open one. Therefore the emergence trap method is not adequate for quantitative surface-related studies, including secondary production.

Etude quantitative comparée de pièges à émergence placés sur substrats libre ou couvert d'un ruisseau : généralités et cas des Trichoptères

Mots-clés : pièges à émergences, émergence quantitative, ruisseau, Trichoptera.

Deux serres ont été utilisées comme pièges à émergence dans un ruisseau du sud de l'Autriche inférieure entre 1984 et 1989. Elles étaient distantes de $28 \mathrm{~m} \mathrm{l'une} \mathrm{de} \mathrm{l'autre.} \mathrm{Le} \mathrm{substrat} \mathrm{au} \mathrm{dessous} \mathrm{des} \mathrm{pièges} \mathrm{était} \mathrm{recouvert} \mathrm{d'une} \mathrm{tôle} \mathrm{une} \mathrm{année} \mathrm{sur} \mathrm{deux,}$ en alternance. Cette tôle empêchait l'émergence des insectes du substrat situé directement sous la serre; ainsi les insectes collectés dans cette serre proviennent de l'extérieur du piège. Les résultats montrent que les insectes qui sont issus de l'extérieur représentent une proportion considérable des captures, mais difficile à quantifier. Pour quelques espèces même, le nombre d'individus dans le piège placé sur substrat couvert était plus élevé que celui du piège dont le substrat était libre. En conclusion, l'usage de pièges à émergence semble ne pas convenir pour des études quantitatives, y compris celles de production secondaire.

\section{Introduction}

When the emergence method was introduced to running - water ecology (Illies 1971) it was thought that the adults caught in the trap had emerged from the stream bed immediately below, so that they could be used for quantitative production studies. The present study was made to find out to what extent the catch in an emergence trap may really have come from the bottom below.

1. Sonnengasse 13, A - 3293 Lunz am See, Austria.
In a recent paper (Malicky 2002, with more references), I discussed the main problems of the method, and presented the results of a comparison of emergence traps of different types. The construction of the traps has an important influence on the results. Also, it was evident that a number of insects in the traps had not emerged from this part of the bottom, or were not freshly emerged at all, such as terrestrial insects or aged ovipositing females. Although the traps were closed to the surrounding air as tightly as possible, an absolute and permanent exclusion of other insects was not possible under field conditions. But even in the funnel traps which were perfectly sealed from the air by water, terrestrial insects were sometimes caught. Therefore, it must not be believed that the total catch, 
which is the total of adults collected in a trap, is identical with the insects emerging from the bed surface exactly covered by the trap.

\section{Material and methods}

This study was made in the upper part of the stream called Kothbergbach near Lunz, Lower Austria $\left(47^{\circ} 52^{\prime} 14^{\prime \prime} \mathrm{N}, 14^{\circ} 58^{\prime} 13^{\prime \prime} \mathrm{E}\right)$ near the farmhouse Presslreith. The site was about $2 \mathrm{~km}$ upstream of the site of the studies described by Malicky (2002). The stream is here $2-3 \mathrm{~m}$ broad, the discharge at low water is about $100 \mathrm{l} / \mathrm{sec}$. The mean water temperature is $11^{\circ} \mathrm{C}$ in summer (June to September), with maxima at about $15-17^{\circ} \mathrm{C}$, and the mean during winter (January to March) is about $2,5^{\circ} \mathrm{C}$, with minima at $0,4^{\circ} \mathrm{C}$. Temperature variation within one week is about $5-6^{\circ} \mathrm{C}$ at all seasons. The sediment consists of dolomite gravel and sand, but $30-50 \mathrm{~cm}$ under the surface is a layer of clay. The catchment area is entirely covered by forest consisting of deciduous trees (Fagus sylvatica, Acer pseudoplatanus and others) with the spruce (Picea abies) dominant. The altitude is $670 \mathrm{~m}$. The stream runs through a small and shallow trout pond a few metres above the study site.
For the study two commercial greenhouses covering $3 \times 3 \mathrm{~m}$ stream bed were set up in a stretch of the stream which looked more or less homogenous (Fig. 1 ), at a distance apart of $28 \mathrm{~m}$. The greenhouses were closed at the edges of the stream so that the covered area was identical with the full width of the stream. The construction was of zinc-plated steel, walls and roofs were of strong glass, with small windows which were closed with $1 \mathrm{~mm}$ mesh-size nylon gauze. Sealing against the water at the upper and lower edges was made with aprons of polyethylene, filled with stones to made them heavy. The greenhouse at the lower position was called $\operatorname{Pr} 1$, the upstream one $\operatorname{Pr} 2$. The greenhouses were there all the time between 1984 and 1989 . The insects were collected with a modified vacuum cleaner and dropped immediately into $70 \%$ ethanol. Collecting in the warm season (about May to September) was on Monday, Wednesday and Friday, in the cold season at irregular occasions when emergence was observed.

In the first and last years (1984 and 1989), both greenhouses were operated in the normal way with open bottoms. In the years between, in one of the two greenhouses the stream bottom below was covered completely with a zinc-plated iron sheet (Fig. 2), whi-

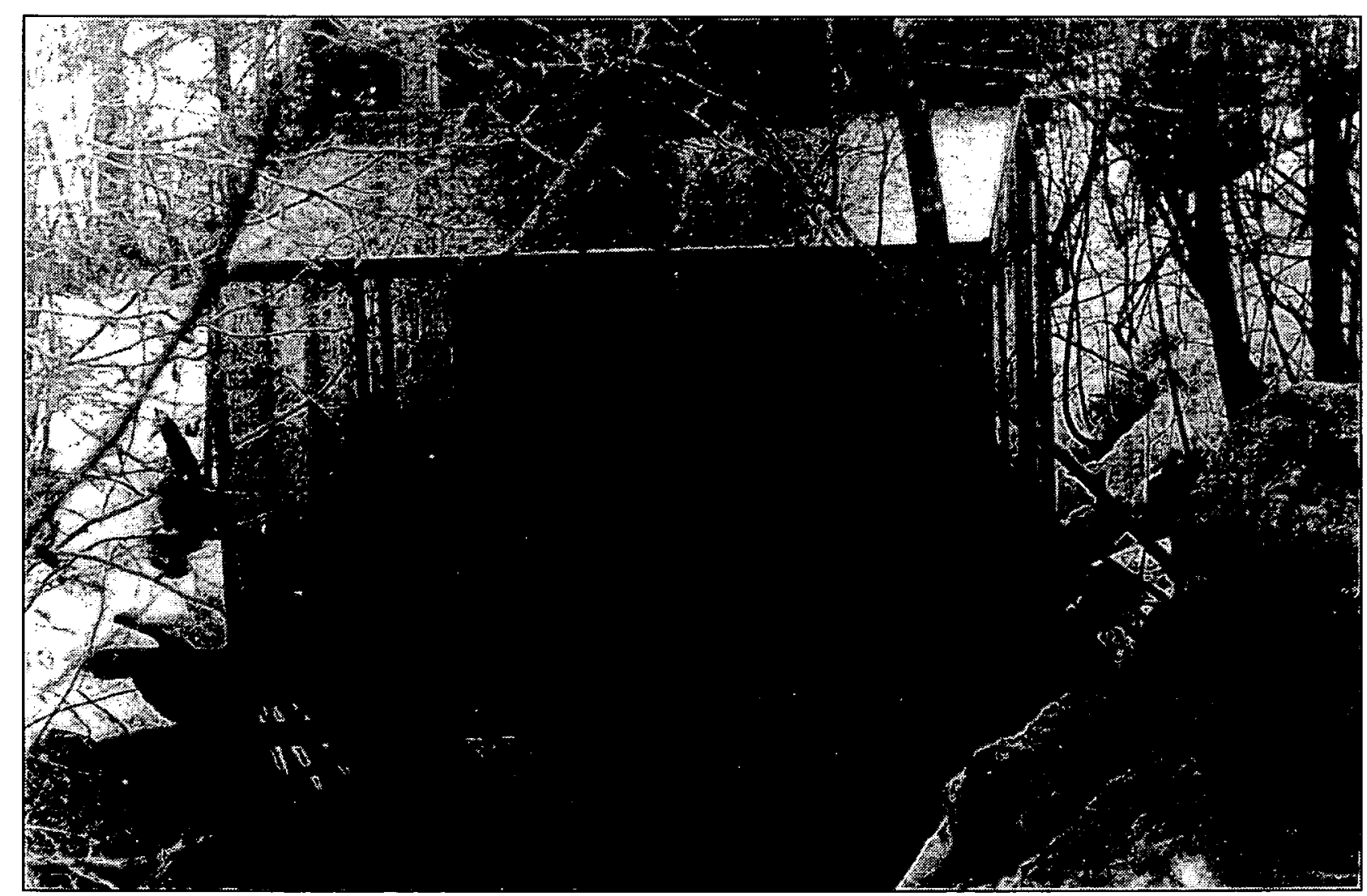

Fig. 1. One of the greenhouses used in the experiment.

Fig. 1. Une serre utilisée dans l'expérience. 
le the bottom of the other was open. This metal cover was changed between the two houses every winter. $\operatorname{Pr} 1$ had a metal cover in 1986 and 1988, Pr2 in 1985 and 1987. This shield was intended to make sure that no insects could emerge from the covered area, which meant that the insects caught in this greenhouse came completely from elsewhere. The metal cover was cleaned regularly with a strong broom so that no insects could settle and develop on its upper surface.

The insects in the catch were counted in their groups; Trichoptera were identified to species and sexed. The detailed data are stored in the Austrian Biogeographical Databank ZOBODAT at Biozentrum Linz and are available there. Here I give annual totals only. The results are so striking that statistical methods are not necessary.

\section{Results and discussion}

\subsection{Comparison of the insect groups between the two traps}

The totals are given in Tables 1 and 2. Both traps had the same size so that a conversion to square units was not necessary. No statistical evaluation is used.

Comparing the mean of the years with open bottom, we see that the two sites at only $28 \mathrm{~m}$ distance were clearly different. In Pr1 there were more Trichoptera, Ephemeroptera and Simuliidae, but in Pr2 more Plecoptera, so the stream bed is evidently not as homogenous as it appears.

Comparing open and covered bottom: if the hypothesis is correct that the catch in a trap comes exactly and exclusively from the bottom below, we had to ex-

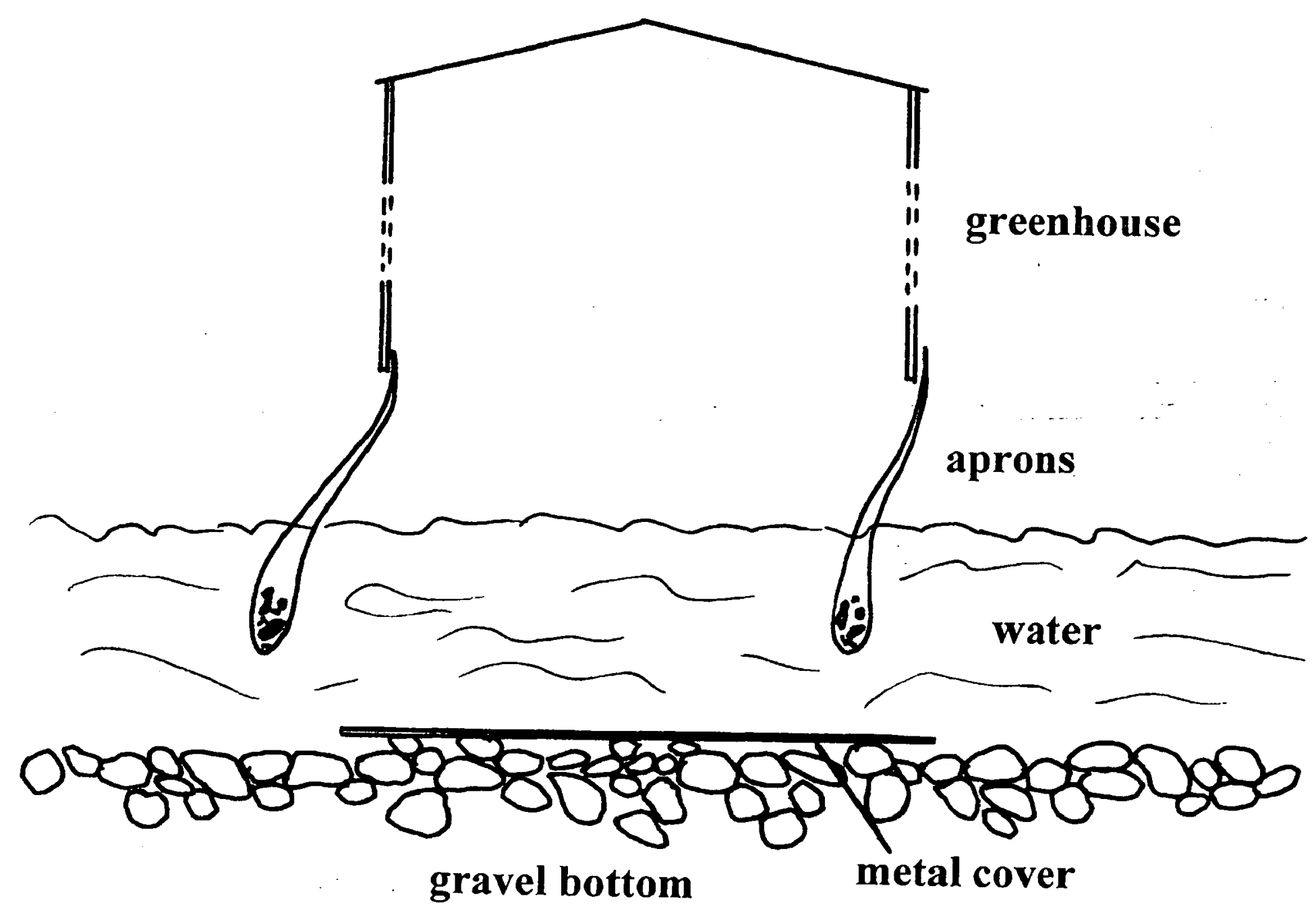

Fig. 2. The arrangement of the experiment with covered bottom.

Fig. 2. Schéma de la serre placée sur substrat couvert. 
Table 1.Annual totals of emergence ; : covered bottom.

Tableau 1.Nombres total des émergences annuelles.

\begin{tabular}{lcccccccccccccc}
\hline & \multicolumn{1}{c}{1984} & \multicolumn{1}{c}{1985} & \multicolumn{1}{c}{1986} & \multicolumn{1}{c}{1987} & \multicolumn{1}{c}{1988} & \multicolumn{2}{c}{1989} \\
\hline Trap n & \multicolumn{1}{c}{} & 1 & 2 & 1 & 2 & 1 & 2 & 1 & 2 & 1 & 2 & 1 & 2 \\
Trichoptera & & & & - & - & & & - & $\square$ & & & \\
Plecoptera & 1998 & 383 & 1805 & 593 & 373 & 536 & 1187 & 346 & 209 & 385 & 649 & 350 \\
Ephemeroptera & 2307 & 2927 & 1694 & 579 & 776 & 1745 & 1678 & 352 & 414 & 1352 & 1299 & 1777 \\
Simuliidae & 1204 & 684 & 1651 & 435 & 269 & 889 & 1135 & 103 & 373 & 625 & 1037 & 934 \\
& 2027 & 747 & 985 & 471 & 1982 & 449 & 1116 & 885 & 891 & 366 & 392 & 268 \\
\hline
\end{tabular}

pect no insects in the traps with covered bottom. It is easy to see in the tables that this was not so. But it is surprising how many insects were in both traps in all years. The immediate conclusion is that only a minor part of the total catch comes from the stream bed below, so that a large proportion is not from emergence but from drift or other origin.

The situation becomes more complicated if we compare the proportion of «non-emergence» (in Table 2, at covered bottom). In the average of Pr1 with covered bottom, there are fewer Trichoptera (26\%), Plecoptera (35\%) and Ephemeroptera (35\%), but clearly more Simuliidae (127\%) than in the other years. In $\operatorname{Pr} 2$, on the other hand, there are fewer Plecoptera $(24 \%)$ and Ephemeroptera (34 \%), but more Trichoptera (113\%) and Simuliidae (148\%) with covered bottom. This becomes more striking if we compare single years. For instance, in $\operatorname{Pr} 2$ in 1985, there were more Trichoptera and in 1987 more Simuliidae with covered bottom than in any year with open bottom. If the total catch increases in some instances with covered stream bed instead of decreasing to zero, it is evident that the catch is not directly related to the bottom area below. Finally, the totals in five instances were lower and in three instances higher with covered bottom than with open stream bed; five to three is close to four to four which would mean perhaps with a little exaggeration that it does not matter if the bottom is covered or not. This means that there is no clear relation between benthic production and emergence, and that the method is quite useless for secondary production studies and other surface-related studies. It appears that an unknown number of unknown factors are influencing the results.

\subsection{Comparison of Trichoptera}

In the six years of operation, 49 species of caddisflies were caught of which 28 were represented by less
Table 2.Means of all years with open and covered bottom.

Tableau 2.Moyenne des émergences annuelles avec le fond de la serre ouvert et couvert.

\begin{tabular}{lcccc}
\hline & \multicolumn{3}{c}{ open } & \multicolumn{3}{c}{ covered } \\
Trap $n^{\circ}$ & 1 & 2 & 1 & 2 \\
\hline Trichoptera & 1420 & 414 & 291 & 470 \\
Plecoptera & 1745 & 1950 & 595 & 466 \\
Ephemeroptera & 1257 & 783 & 321 & 269 \\
Simuliidae & 1130 & 458 & 1437 & 678 \\
\hline
\end{tabular}

than 10 specimens. The 11 most abundant species are presented in Table $3 \& 4$.

As in the total numbers of insects, the totals of Trichoptera species are lower in $\operatorname{Pr} 2$, the reason for which is not clear. One could expect that the upper greenhouse had caught already many of the drifting specimens so that they were fewer in the lower one, but it is just the contrary. In $\operatorname{Pr} 1$ there were clearly fewer specimens of all species with the covered bottom. Pr2 had only five species fewer, but four species were represented by higher numbers under the same conditions.

With the comparison of the means, the percentage of some females is added. (Table 4).

Normally the proportions of males and females are alike, which means, in most cases, that a proportion of about $50 \%$ females indicates a dominance of freshly emerged specimens (see the discussion in Malicky 2002). Comparing male-female ratios, we find similar figures in both greenhouses with open or covered bottoms. Odontocerum albicorne is an exception with a usually low proportion of females, and Ecclisopteryx guttulata and Hydropsyche tenuis have clearly higher female percentages which probably results from many 
Table 3. Annual totals of Trichoptera emergence ; $\mathbf{0}$ : covered bottom:

Tableau 3. Nombre total d'émergences de Trichoptères selon les années.

\begin{tabular}{lccccccccccccc}
\hline Trap n & \multicolumn{1}{c}{1984} & \multicolumn{1}{c}{1985} & \multicolumn{1}{c}{1986} & \multicolumn{1}{c}{1987} & \multicolumn{2}{c}{1988} & \multicolumn{1}{c}{1989} \\
& 1 & 2 & 1 & 2 & 1 & 2 & 1 & 2 & 1 & 2 & 1 & 2 \\
\hline Rhyacophila tristis & 68 & 28 & 106 & 37 & 19 & 42 & 230 & 14 & 20 & 79 & 114 & 41 \\
R. vulgaris & 169 & 42 & 31 & 4 & 5 & 14 & 37 & 3 & 6 & 11 & 7 & 10 \\
Glossosoma conformis & 393 & 73 & 238 & 90 & 42 & 77 & 333 & 178 & 31 & 56 & 286 & 133 \\
Philopotamus ludificatus & 94 & 50 & 129 & 24 & 11 & 47 & 26 & 9 & 23 & 29 & 16 & 14 \\
Wormaldia copiosa & 23 & 10 & 86 & 78 & 10 & 43 & 5 & 3 & 5 & 16 & 7 & 12 \\
Hydropsyche tenuis & 250 & 25 & 315 & 32 & 25 & 24 & 107 & 7 & 28 & 34 & 25 & 17 \\
Tinodes dives & 51 & 35 & 34 & 87 & 6 & 19 & 34 & 48 & 4 & 12 & 31 & 27 \\
Micrasema minimum & 176 & 33 & 77 & 95 & 8 & 32 & 54 & 29 & 16 & 18 & 11 & 18 \\
Ecclisopteryx guttulata & 21 & 10 & 19 & 5 & 3 & 3 & 21 & 4 & 2 & 1 & 12 & 1 \\
Silo pallipes & 509 & 70 & 587 & 114 & 226 & 191 & 260 & 41 & 57 & 81 & 97 & 45 \\
Odontocerum albicome & 34 & 3 & 72 & 0 & 5 & 2 & 14 & 1 & 4 & 17 & 2 & 5 \\
\hline
\end{tabular}

Table 4. Means of Trichoptera emergence in all years with open and covered bottom, and percentage of females.

Tableau 4. Moyennes des émergences annuelles des espèces de Trichoptères avec le fond de la serre ouvert et couvert et pourcentage de femelles.

\begin{tabular}{|c|c|c|c|c|c|c|c|c|}
\hline \multirow{3}{*}{ Trap $n^{\circ}$} & \multicolumn{4}{|c|}{ open } & \multicolumn{4}{|c|}{ covered } \\
\hline & \multicolumn{2}{|c|}{1} & \multicolumn{2}{|c|}{2} & \multicolumn{2}{|c|}{1} & \multicolumn{2}{|c|}{2} \\
\hline & $M$ & $\%$ \% & $\mathbf{M}$ & $\%$ 오 & $\mathbf{M}$ & $\%$ & $\mathbf{M}$ & $\%$ \\
\hline Rhyacophila tristis & 130 & 60 & 48 & 52 & 20 & 49 & 26 & 40 \\
\hline Rhyacophila vulgaris & 61 & 53 & 19 & 47 & 6 & 27 & 4 & 47 \\
\hline Glossosoma conformis & 313 & 59 & 85 & 49 & 37 & 62 & 134 & 45 \\
\hline Philopotamus Iudificatus & 66 & 45 & 35 & 35 & 17 & 56 & 17 & 42 \\
\hline Wormaldia copiosa & 30 & 47 & 20 & 40 & 8 & 33 & 41 & 33 \\
\hline Hydropsyche tenuis & 174 & 54 & 26 & 42 & 27 & 72 & 20 & 56 \\
\hline Tinodes dives & 38 & 55 & 23 & 39 & 5 & 40 & 68 & 42 \\
\hline Micrasema minimum & 80 & 42 & 25 & 60 & 12 & 42 & 62 & 41 \\
\hline Ecclisopteryx guttulata & 18 & 75 & 4 & 53 & 3 & 80 & 5 & 67 \\
\hline Silo pallipes & 363 & 38 & 97 & 38 & 71 & 55 & 39 & 31 \\
\hline Odontocerum albicome & 28 & 32 & .7 & 19 & 5 & 22 & 1 & 0 \\
\hline
\end{tabular}


aged, ovipositing females in the catch. Micrasema minimum was helpful in the other study because at other sites and in other traps aged females with empty abdomens were dominant. Here it had a normal male-female ratio with only 24 aged females of a total of 567 in six years, which means only $4 \%$. As in the totals of insect groups in tables 1 and 2, the annual sum or even the average of all years (e.g. in G. conformis, W. copiosa, T. dives and M. minimum in $\operatorname{Pr} 2$ ) of individual species was sometimes higher with covered bottoms. Only experiments could explain this phenomenon.

One could try to prevent the entrance of insects from outside by very careful sealing of the trap not only against the air but also the water outside, i.e. a screen from the lower edge of the trap to some depth of the sediment. This is difficult under field conditions, but the major objection is that the connection with the population outside is cut off, so that the substrate under the trap would be empty after one year.
In conclusion, this experiment has shown that the emergence method is not adequate for stream bed-related quantitative studies, in particular on secondary production. This will however not affect the importance of the method for non-quantitative studies.

\section{Acknowledgments}

I am particularly indebted to Erich Lanzenberger for his care for the greenhouses and for the regular and time-consuming collections over more than six years. He was occasionally supported by other helpers including Alfred Aigner, Fritz Aigner and Arnold Leichtfried. Joachim Illies and Peter Zwick supported the work by donation of the greenhouses. M. Ian Crichton read the English text. To all of them my sincere thanks.

\section{References}

Illies J. 1971. — Emergenz 1969 im Breitenbach. Arch. Hydrobiol., $69: 14-59$.

Malicky H. 2002. - A quantitative field comparison of different types of emergence traps in a stream: general, Trichoptera, (Diptera Limoniidae and Empididae). Ann. Limnol., 38(2) : 133-149. 